\title{
A FINITE ELEMENT ANALYSIS STUDY OF FOOTWEAR LOWER ENSEMBLE INFLUENCE ON THE PLANTAR PRESSURE DISTRIBUTION
}

\author{
ANALIZA ÎN ELEMENT FINIT A INFLUENTEI STRUCTURII ANSAMBLULUI INFERIOR AL ÎNCĂLTĂMINTEI \\ ASUPRA DISTRIBUTIEI PRESIUNILOR PLANTARE
}

\author{
Răzvan MOCANU*, Ioan CIOARĂ \\ "Gheorghe Asachi" Technical University of laşi, Faculty of Textiles \& Leather Engineering and Industrial Management
}

\begin{abstract}
A FINITE ELEMENT ANALYSIS STUDY OF FOOTWEAR LOWER ENSEMBLE INFLUENCE ON THE PLANTAR PRESSURE DISTRIBUTION
ABSTRACT. The plantar pressure distribution has a complex influence on the kinetics and kinematics of the lower limbs. The foot bed-outsole ensemble must provide the correct support of the foot and add corrections if necessary, in order to adjust the pressure distribution on the foot plantar surface. A poorly designed outsole, a feeble midsole or the incorrect care and use of the footwear product will lead to the deterioration of the foot bed functionality. The degree of the foot bed deterioration can be determined using in-shoe plantar pressure measuring devices. This loss of functionality must be prevented as much as possible in the design stage. Footwear prototyping and wearing tests are very expensive and time consuming and do not represent a viable method in economic terms. The fastest and less expensive testing method suitable for footwear production in design stages is the Finite Element Analysis. To use this method we developed a 3D CAD model of the human foot using as model a real 3D scanned foot. The scanned foot was processed in various 3D CAD systems in order to obtain a FEA usable 3D part. The developed model was used to determine how the ensemble of a specific sole design and a midsole with wear characteristics modify the plantar pressure distribution.
\end{abstract}

KEY WORDS: footwear, outsole, CAD, FEA

ANALIZA ÎN ELEMENT FINIT A INFLUENTEI STRUCTURII ANSAMBLULUI INFERIOR AL ÎNCĂLTĂMINTEI ASUPRA DISTRIBUTIEI PRESIUNILOR PLANTARE

ABSTRACT. Distribuţia presiunilor plantare influenţează într-un mod complex cinetica şi cinematica membrelor inferioare. Ansamblul inferior al încălţămintei trebuie să asigure susţinerea corectă a piciorului şi să aducă ajustări, dacă este necesar, pentru a corecta distribuţia presiunilor pe suprafaţa plantară. 0 talpă incorect proiectată, un branț defectuos sau incorecta îngrijire şi utilizare a produsului de încălţăminte va duce la deteriorarea funcţionalităţii ansamblului inferior. Gradul de deteriorare poate fi determinat prin utilizarea sistemelor de măsurare a presiunilor plantare în încălţăminte. Această pierdere a funcţionalităţii trebuie prevenită pe cât posibil în faza de proiectare. Prototiparea şi testele în utilizare sunt foarte scumpe, necesită mult timp şi nu reprezintă o metodă viabilă din punct de vedere economic. Cea mai rapidă şi necostisitoare metodă de testare potrivită pentru producţia de încălţăminte în faza de proiectare este Analiza în Element Finit. Pentru utilizarea acestei metode am proiectat un model 3D CAD al piciorului uman utilizând ca model un picior real, scanat 3D. Piciorul scanat a fost procesat într-o serie de sisteme 3D CAD pentru a obţine o piesă tridimensională, utilizabilă în AEF. Modelul proiectat a fost utilizat pentru a determina modul în care ansamblul format dintr-un anumit model de talpă şi un branţ cu proprietăţile fizice ale unui branţ uzat; modifică distribuţia presiunilor plantare.

CUVINTE CHEIE: încălţăminte, talpă, CAD, AEF

L'ANALYSE PAR ÉLÉMENTS FINIS DE L'INFLUENCE DE LA STRUCTURE DU DESSOUS DE LA CHAUSSURE SUR LA RÉPARTITION DES PRESSIONS PLANTAIRES RÉSUMÉ. La répartition des pressions plantaires influence dans une manière complexe la cinétique et la cinématique des membres inférieurs. Le dessous de la chaussure doit offrir un soutien adéquat pour le pied et faire les ajustements nécessaires pour corriger la répartition des pressions sur la surface plantaire. Une semelle mal conçue, une semelle intermédiaire défectueuse ou l'utilisation et soin erronées de la chaussure endommageront le fonctionnement du dessous de la chaussure. Le degré d'altération peut être déterminé au moyen du système de mesure des pressions plantaires dans la chaussure. Cette perte de fonctionnalité doit être évitée autant que possible dans la phase de conception. Le prototypage et les tests d'utilisation sont coûteux, longs et ne représentent pas une méthode viable du point de vue économique. La plus rapide et peu coûteuse méthode de test appropriée pour la production de la chaussure dans la phase de conception est I'analyse par éléments finis. Pour utiliser cette méthode, nous avons conçu un modèle de CAO 3D du pied humain en utilisant le modèle de pied réel 3D numérisé. Le pied à analyser a été passé dans un nombre de systèmes de CAO 3D afin d'obtenir une pièce en trois dimensions utilisée dans la FEA. Le modèle conçu a été utilisé pour déterminer la manière dont le dessous de la chaussure, formé d'un modèle particulier de semelle et une semelle intermédiaire ayant les propriétés physiques d'une semelle intermédiaire usée, change la répartition des pressions plantaires.

MOTSCLÉS: semelles, chaussure, CAO, FEA

\section{INTRODUCTION}

The footwear sole weight removal cavities structure and the materials used for the midsole have a major influence on the distribution of the plantar surface pressures [1, 2]. The midsole deteriorates over

\section{INTRODUCERE}

Structura golurilor de uşurare ale tălpii şi materialele utilizate în producţia branţului au o influenţă semnificativă asupra distribuţiei presiunilor plantare [1, 2]. Branţul se deteriorează cu timpul sub

*Correspondence to: Răzvan MOCANU, 10 Dr. Savini; H3 building; entrance A; 2nd floor; apt. 3; lași-700320; lași, e-mail: razvan_mocanu@yahoo.com 
time under the influence of a set of factors. These factors include the characteristics of the material used for the midsole, but also the usage of the footwear product [3-6]. An improper maintenance of the product, correlated with the midsole structure and materials, will lead to changes of the physical properties and the loss of functional features of the footwear lower ensemble. The functional losses render the product unusable. However, the deteriorated product is still used by individuals with peripheral neuropathy, leading to short and long term lower limb injuries.

To determine the deterioration degree and to prevent foot injuries, wearing tests on prototype products should be performed. This method is very expensive and time consuming and is not economically viable.

This paper describes a method developed by the authors to estimate the changes of the plantar pressures distribution according to the physical characteristics of the midsole and the weight removal cavities structure.

\section{MATERIALS AND METHODS}

The method used to estimate the plantar pressure changes consists in the development of a 3D CAD (Three Dimensional Computer Aided Design) model and the use of FEA (Finite Element Analysis).

To accomplish this, the three parts interacting in the model were designed. The industry uses CAD as the method of choice for sole and midsole design [7], therefore the sole and midsole used in the analysis were completely developed and defined in a CAD system. However, to obtain estimation results as close to reality as possible, a real human foot was the starting point in the 3D part development.

The INFOOT three dimensional foot scanner, presented in Figure 1, was used to digitize the foot surface [8].

This system uses the optical laser scanning method to scan the foot form. The raw data is presented as point cloud and can be converted in various scalar file formats. The scanning step accuracy is $0.5 \mathrm{~mm}$, the scanning speed is up to $30 \mathrm{~mm} / \mathrm{sec}$, the full scanning and data processing takes about 10 influenţa unui cumul de factori. Aceşti factori includ caracteristicile materialului utilizat pentru producţia branţului, dar şi modul de utilizare a produsului de încălţăminte [3-6]. O îngrijire incorectă a produsului, corelată cu structura şi materialele ansamblului inferior, duc la schimbări ale proprietăţilor fizice şi la pierderea caracteristicilor funcţionale ale acestui ansamblu. Pierderea caracteristicilor funcţionale conduce la un produs care nu se pretează utilizării. Cu toate acestea, produsul deteriorat este utilizat de către persoane cu neuropatie periferică, ceea ce cauzează afecţiuni pe termen scurt şi pe termen lung la nivelul membrelor inferioare.

Pentru a determina gradul de deteriorare şi pentru a preveni afecţiunile la nivelul piciorului, sunt necesare o serie de teste pe produse prototip. Această metodă este foarte scumpă şi necesită mult timp, nefiind viabilă din punct de vedere economic.

În această lucrare este descrisă o metodă dezvoltată de autori pentru a estima modificările distribuţiei presiunilor plantare în corelaţie cu caracteristicile fizice ale branţului şi cu structura golurilor de uşurare.

\section{MATERIALE ŞI METODE}

Metoda utilizată pentru estimarea schimbărilor presiunilor plantare constă în dezvoltarea unui model CAD 3D (Three Dimensional Computer Aided Design proiectarea tridimensională cu ajutorul calculatorului) şi utilizarea AEF (Analiză în Element Finit).

Pentru realizarea studiului se proiectează cele trei componente care interacţionează. Industrial, se utilizează metoda CAD ca metodă de proiectare a tălpilor şi a branţurilor [7], astfel talpa şi branţul utilizate în analiză sunt complet proiectate şi definite într-un sistem CAD. Pentru a obţine rezultate cât mai precise s-a utilizat modelul real al unui picior pentru proiectarea modelului 3D.

Digitizarea suprafeţei piciorului s-a realizat prin intermediul unui scanner INFOOT prezentat în Figura 1.

Acest sistem utilizează scanarea optică pe bază de laser pentru scanarea formei piciorului [8]. Datele brute sunt prezentate sub formă de nor de puncte şi pot fi convertite în diferite formate de fişiere scalare. Scanarea se realizează cu o precizie a pasului de $0.5 \mathrm{~mm}$, cu o viteză de $30 \mathrm{~mm} / \mathrm{sec}$, iar întreg procesul de scanare durează 
sec/foot. A model of the raw data, processed polygon mesh and surface model are presented in the Figure 2. aproximativ 10 secunde pentru fiecare picior. Reprezentarea datelor brute, reţeaua poligonală procesată şi suprafaţa modelului sunt prezentateîn Figura 2.

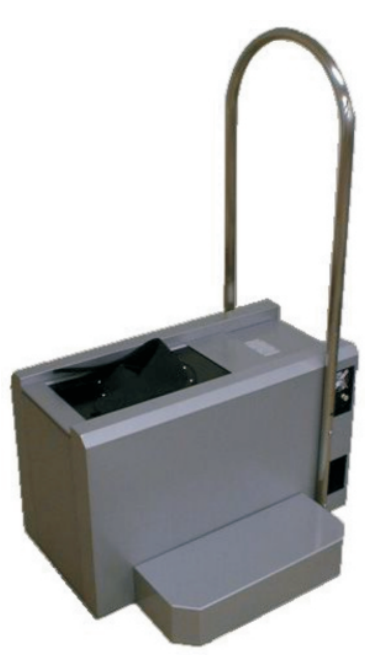

Figure 1. INFOOT laser scanner

Figura 1. Scanner laser INFOOT
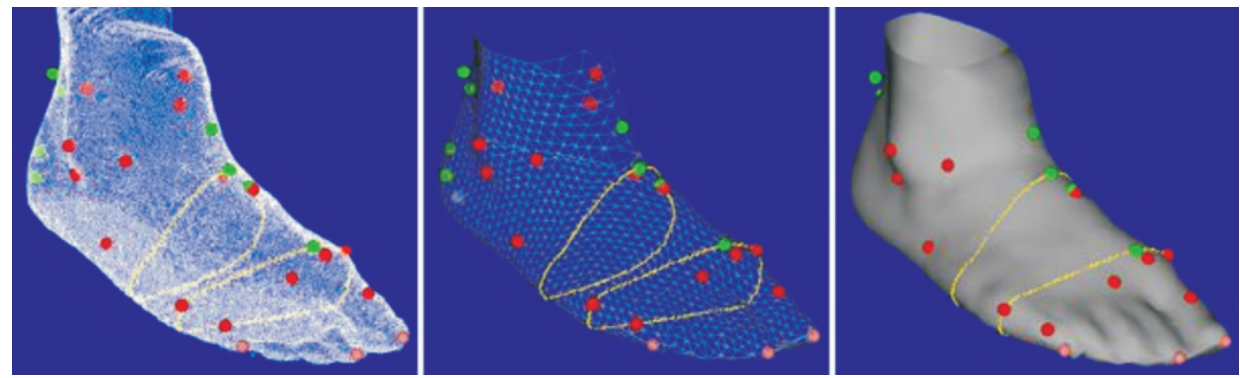

Figure 2. Scanned data

Figura 2. Date scanate

The 3D CAD systems are using vectorial data. Even if these systems are able to import scalar data, this data can be used only as reference. In order to obtain a usable mesh, the raw data is processed in a mesh processing application. The MeshLab v1.3.2 64 bit was used to import, analyse and process the raw data. The imported scanned foot is presented in Figure 3.
Sistemele de proiectare tridimensională CAD utilizează date vectoriale. În cazul în care aceste sisteme pot importa date scalare, respectivele date pot fi utilizate numai ca referinţă. Pentru a obţine o structură utilizabilă, datele de intrare sunt procesate iniţial într-o aplicaţie de procesare a structurilor scalare. Pentru importul, analiza şi procesarea datelor de intrare s-a utilizat aplicaţia MeshLab v1.3.2 64bit. Piciorul scanat şi importat în aplicaţie este prezentat în Figura 3. 


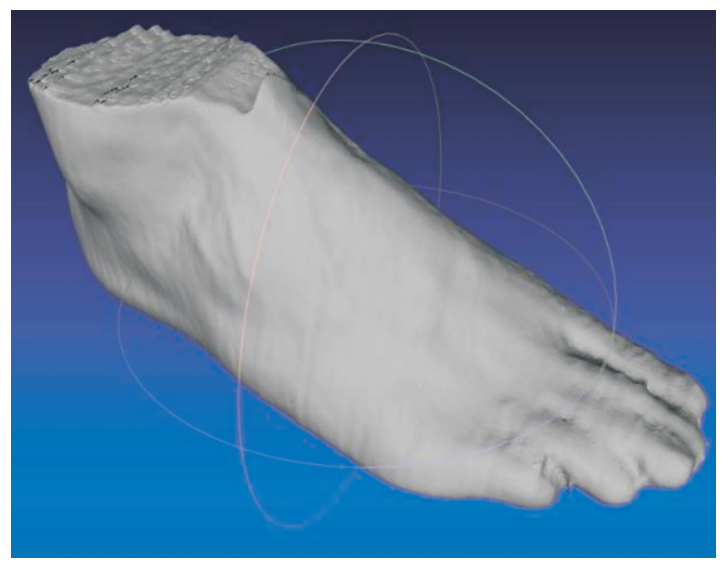

Figure 3. MeshLab imported raw data

Figura 3. Date importate în MeshLab

Laser scanning point clouds are usually high density clouds. For the purpose of obtaining a 3D usable part, the point density must be down sampled. The Mesh Element Subsampling function is used to reduce the number of vertices, edges or faces. As the scanned model is defined by points, the option used is vertex subsampling. The processed model, presented in Figure 4, did not lose definition quality through the subsampling process because the scanned model is over defined.
Norul de puncte obţinut prin scanarea laser este în general de densitate mare. Pentru a obţine un model 3D utilizabil în analiză, trebuie redusă densitatea norului de puncte. Funcţia Mesh Element Subsampling este utilizată pentru reducerea numărului de puncte, muchii sau suprafeţe. Deoarece modelul scanat este definit prin puncte, opţiunea utilizată este cea de reducere a numărului de puncte. Modelul procesat, prezentat în Figura 4, nu a pierdut în calitatea definiţiei prin procesul de reducere a punctelor, deoarece modelul scanat este supra definit.

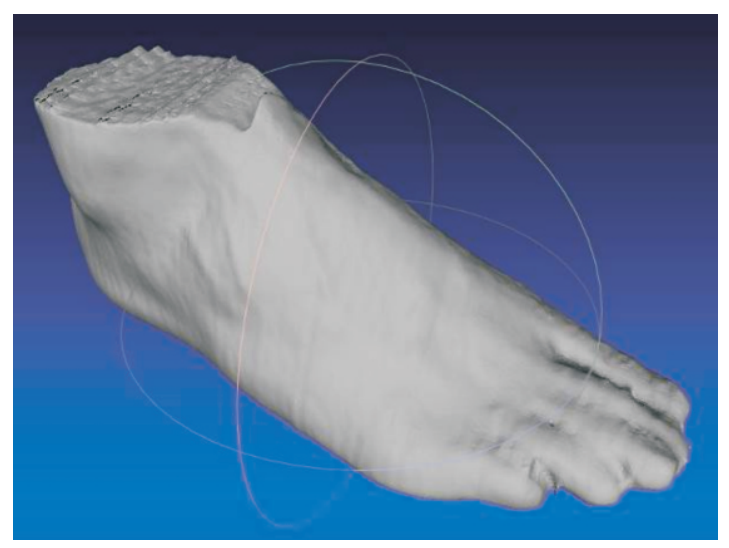

Figure 4. Processed mesh

Figura 4. Reţea procesată

The subsampling degree should be tuned to not deteriorate the mesh quality. Once the optimum vertex density is obtained, the mesh is used to create the 3D part. SolidWorks 2013 64bit [9] was used for the part modelling. The mesh is imported in the application workspace. The import process uses high computing
Gradul de reducere a numărului de noduri trebuie ajustat pentru a nu deteriora calitatea reţelei. După obţinerea densităţii optime de noduri, reţeaua poate fi utilizată pentru crearea unei componente 3D. Pentru modelarea componentei 3D s-a utilizat SolidWorks 2013 64bit [9]. Reţeaua este iniţial importată în spaţiul de lucru al aplicaţiei. Procesul de import utilizează o 
resources. A high speed quad processor computer will need about five hours to import the model and the imported model will use about $4 \mathrm{~GB}$ of the available RAM. The result is a set of surfaces, presented in Figure 5. cantitate semnificativă de resurse computaţionale. O unitate cu procesor de mare viteză, cu patru nuclee, va necesita aproximativ cinci ore pentru a importa modelul şi va utiliza aproximativ 4GB din memoria RAM disponibilă. Rezultatul constă într-un set de suprafeţe, prezentat în Figura 5.

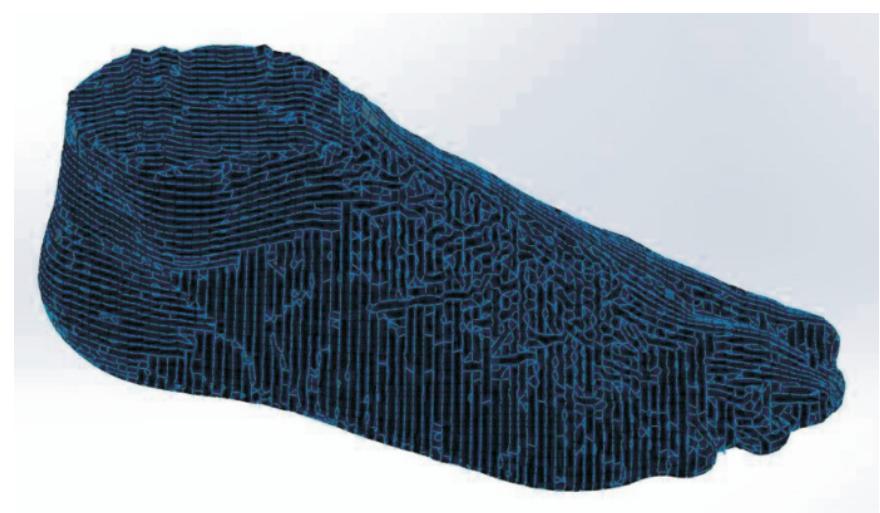

Figure 5. Imported mesh

Figura 5. Structura importată

By processing this mesh, a solid body is obtained. This solid part, presented in Figure 6 , is the vectorial representation of the scanned foot.
Prin procesarea acestei reţele se obţine un corp solid. Acest corp solid, prezentat în Figura 6, este reprezentarea vectorială a piciorului scanat.

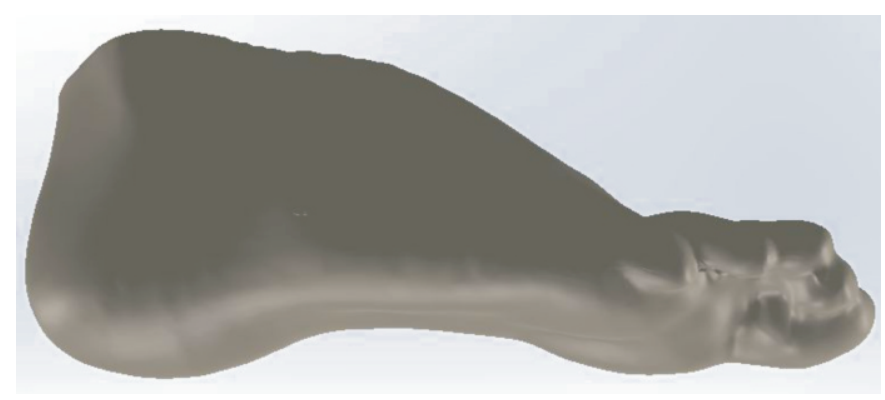

Figure 6. Solid part defined

Figura 6. Corp solid

Once the solid part is defined, it is fully usable for FEA.

The next step consists in defining the midsole and the sole. These two parts are designed directly in the $C A D$ system, obtaining fully defined vectorial parts.

While designing the sole, the emphasis was put on the structure of the weight removal cavities. This is one of the multiple possible patterns. The wireframe representation of the sole is presented in Figure 7.
Odată definit corpul solid, acesta poate fi utilizat în AEF.

Următorul pas constă în definirea branţului şi a tălpii. Aceste două componente sunt proiectate direct în sistemul CAD, obţinând astfel componente vectoriale complet definite.

În proiectarea tălpii s-a pus accentul pe structura golurilor de uşurare. Modelul realizat este unul dintr-o gamă largă de modele posibile. Reprezentarea structurală a tălpii este prezentată în Figura 7. 


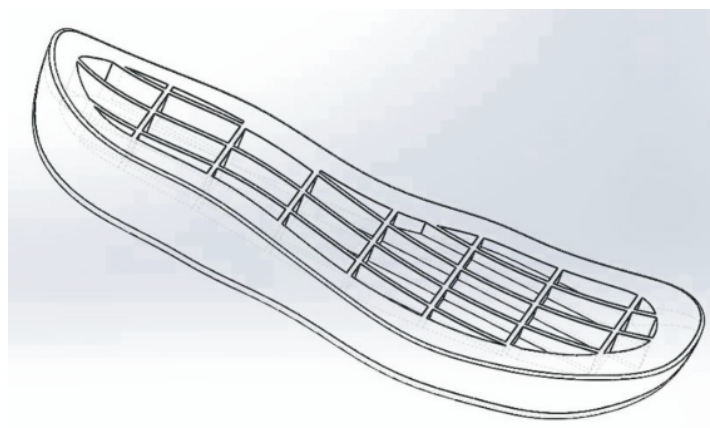

Figure 7. The wireframe representation of the sole

Figura 7. Reprezentarea structurală a tălpii

The midsole is designed starting from the top surface of the sole, as it has to fit as precisely as possible to this surface. The designed midsole is presented in Figure 8 in wireframe configuration.
Branţul este proiectat pornind de la suprafaţa superioară a tălpii, deoarece branţul trebuie să se îmbine cât mai precis cu talpa. Branţul proiectat este prezentat în configuraţie structurală în Figura 8.

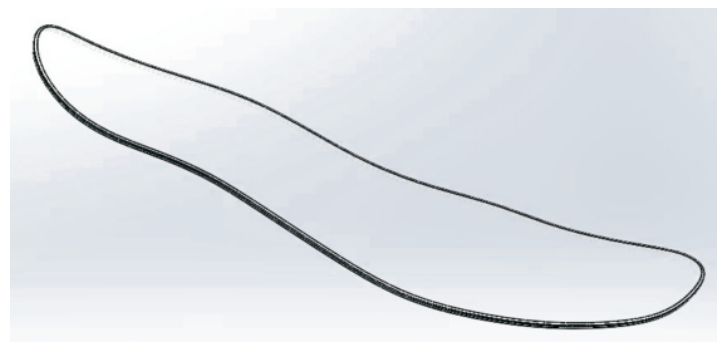

Figure 8. The wireframe representation of the midsole

Figura 8. Reprezentarea structurală a branţului

Using the designed parts, an assembly is designed in order to perform the analysis [10]. This assembly is presented in Figure 9.
Utilizând componentele proiectate se configurează ansamblul care va fi utilizat în analiză [10]. Acest ansamblu este prezentat în Figura 9.

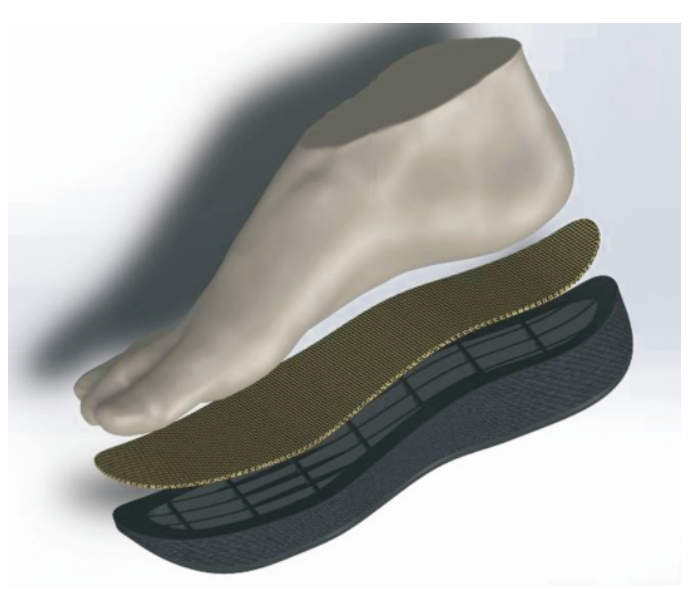

Figure 9. Assembly model

Figura 9. Model ansamblu 


\section{RESULTS AND DISCUSSIONS}

The FEA process is executed for a sample individual with the following characteristics: weight = $80 \mathrm{~kg}$, foot size $=$ EU41. Using both new and worn midsole physical characteristics, the plantar pressure distribution is obtained for both cases. Figure 10 presents the result for the new midsole.

\section{REZULTATE ŞI DISCUTII}

Procesul AEF este realizat pentru cazul concret al unei persoane cu următoarele caracteristici: greutate $=$ $80 \mathrm{~kg}$, număr mărime $=$ EU41. Utilizând atât caracteristicile fizice ale unui branţ nou, cât şi pe cele ale unui branţ uzat, se obţine distribuţia presiunilor plantare pentru ambele cazuri. În Figura 10 este prezentat rezultatul pentru analiza branţului nou.

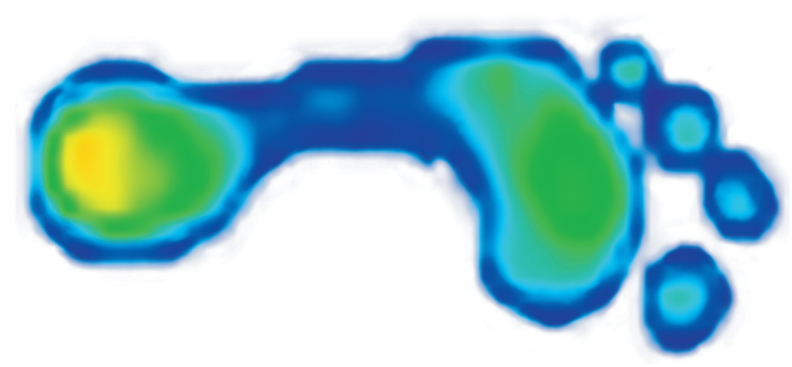

Figure 10. FEA results for new midsole

Figura 10. Rezultate AEF pentru branţ nou

The plantar pressure distribution is close enough to the average foot on a flat surface.

After running the FEA process on the used midsole, the result obtained shows a significant modification of the plantar pressure distribution as presented in Figure 11.
Distribuţia presiunilor plantare este foarte asemănătoare cu distribuţia presiunilor plantare ale unui picior comun în contact cu o suprafaţă plană.

După analiza în cazul branţului uzat, rezultatul obţinut prezintă modificări semnificative ale distribuţiei presiunilor plantare, după cum este prezentat în Figura 11.

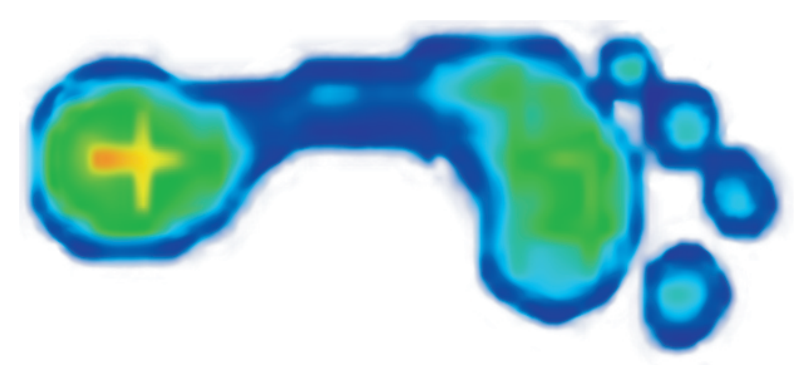

Figure 11. FEA results for the worn midsole

Figura 11. Rezultate AEF pentru branţul uzat

The pressures concentrate on the ribs of the weight removal cavities. The highest pressure is on the ribs located in the heel region. However, there is significant pressure concentrated on the ribs in the metatarsophalangeal joints area also.
Presiunile sunt concentrate pe nervurile golurilor de uşurare. Cea mai mare presiune este localizată la nivelul nervurilor din zona călcâiului. În zona articulaţiilor metatarsofalangiene se observă, de asemenea, o concentraţie a presiunii la nivelul nervurilor. 


\section{CONCLUSIONS}

By using the method developed in this paper, the footwear product functionality can be estimated in a short time with minimum financial costs. This enables the analysis of different materials used for the midsole fabrication and choosing the optimal material without prototype fabrication and time consuming wearing tests.

\section{CONCLUZII}

Utilizând metoda dezvoltată în această lucrare, funcţionalitatea produsului de încălţăminte poate fi estimată într-un timp scurt, cu costuri minime. Acest lucru permite analiza mai multor materiale utilizate în fabricaţia branţului şi selectarea materialului optim fără a fi necesară fabricarea de prototipuri şi fără teste de uzură costisitoare.

\section{REFERENCES}

1. Nigg, B.M., Stefanyshyn, D., Cole, G., Stergiou, P., Miller, J., The effect of material characteristics of shoe soles on muscle activation and energy aspects during running, J. Biomech., 2003, 36, 569-575.

2. Zhang, X., Li, B., Influence of in-shoe heel lifts on plantar pressure and center of pressure in the medial-lateral direction during walking, Gait Posture, 2014, 9, 1012-1016.

3. Perry, S.D., Radtke, A., Goodwin, C.R., Influence of footwear midsole material hardness on dynamic balance control during unexpected gait termination, Gait Posture, 2007, 25, 94-98.

4. Healy, A., Naemi, R., Chockalingam, N., The effectiveness of footwear as an intervention to prevent or to reduce biomechanical risk factors associated with diabetic foot ulceration: A systematic review, J. Diabetes Complicat., 2013, 27, 391-400.

5. Shariatmadari, M.R., English, R., Rothwell, G., Effects of temperature on the material characteristics of midsole and insole footwear foams subject to quasi-static compressive and shear force loading, Mater. Design, 2012, 37, 543-559.

6. Verdejo, R., Mill, N.J., Simulating the effects of long distance running on shoe midsole foam, Polym. Test., 2004, 23, 567-574.

7. Sahin, M., Mihai, A., Yaldiz, S., Pãotinã, M., A Multilingual Virtual Environment for Shoe Design Training. ICVL 2009, Bucharest University Press, ISSN: 1844-8933, Section-Technologies, 214.

8. Pãotinã, M., Mihai, A., 3D Modelling and Rapid Prototyping of Lasts Used to Obtain Special Footwear for Patients with Arthritis, ICAMS 2010, Advanced Materials and Systems, Proceedings of 3rd International Conference, 2010, Bucharest, Romania, ISSN 2068-0783, 283.

9. http://www.solidworks.com/sw/resources.htm (accessed on 18.12.2013).

10. http://www.solidworks.com/sw/products/simulation/finite-element-analysis.htm (accessed on 18.12.2013).

Article received/Data primirii articolului: 12.01.2014

Accepted/Acceptat la data: 17.06.2014 